\title{
Anthropology of Contemporary Issues
}

A SERIES EDITED BY

ROGER SANJEK

Chinatoun No More: Taiuan Immigrants in Contenqorary New York BY HISIANG-SHLI CHEX

Farm Work and Fieldwork: American Agriculture in Anthropological Perspective EDITED BY MIChAEL CHIBNIK

The Varieties of Ethric Experience: Kinship, Class, and Gender among California

Italian-Americans hy MiCAFLA Di LEOKARDO

Lord, I'm Coning Home: Fereyday Aesthetics in Tidewater North Cardina BY JOHN FORREST

Chinese Working-Class Lives: Getting By in Taiwan BY HIILI. GaTES

Accommodation without Assinilation: Sikh Inunigrants in an American High

School

by Marganet A. Gibson

Praying for Justice: Fath, Order, and Community in an American Toun by CaRol, J. Grewholse

Distant Companions: Senants and Employers in Zambia, 1900-1985

By Karex TraNBERg HaNSEX

Rx: Spiritist as Needed: A Study of a Puerto Rican Community Mental Health

Resource

BY AIAAN HIARWOOD

Caribbean New York: Black Immigrants and the Politics of Race By PHILIP KaSINITZ

The Solitude of Collectivism: Romanian Villagers to the Revolution and Beyond BY IDNVID A. KIDYCKEL

Nuclear Stmmer: The Clash of Comntunities at the Seneca Women's Peace.

Encampment

By LOLISE KHASNIEWICZ

Betueen Two Worlds: Ethnographic Fssays on American Jeury EDITED BY JaCK KUGELMASS

American Odyssey: Haitians in New York City BY Michei, S. LaguerRE

From Working Daughters to Working Mothers: Inmigrant Women in a Neu England Industrial Communty By LOLISE LAMPHERE 
Sunbelt Working Mothers: Reconciling Family and Factory

by Louise Lamphene, Patricia Zaveila, and Felipe Gonzal,es, with Peter B. Evans

Creativity/Anthropology EDITEd by SMadar Lavif, Kirin Namayan, and Rewato Rosaldo

Lesbian Mothers: Accounts of Gender in American Culture BY EIILEN LEWIN

Civilized Women: Gender and Prestige in Southeastern Liberia by MaRy H. MORAN

The Magic City: Unemplotyment in a Working-Class Community BY GREGORY PAPPAS

State and Family in Singapore: Restructuring an Industrial Society BY JANET W. SALAFF

Uneasy Endings: Daily life in an American Nursing Home BY RENÉE ROSE SHIET.D

Children of Circumstances: Israeli Emigrants in Neu York BY MOSHF SHOKEID

History and Power in the Study of Lau: Ncu Directions in Legal Anthropology EidTED BY JUNE STARR aNd J ANE F COLIIER

"Getting Paid": Youth Crime and Work in the Imer City By Mercer L. SULIIIVAN

City of Green Benches: Grouing old in a New Dountoun hy MARIA D. VESPERI

Renunciation and Reformulation: A Study of Conversion in an American Sect BY HARRIET WhITEHEAD

Upscaling Downtown: Stalled Gentrification in Washington, D.C. BY BRETT WILLIAMS

Women's Work and Chicano Families: Camery Workers of the Santa Clara Valley by Patricia Zaveisia 